\title{
Study on the hydraulic conductivity by constant and falling head methods for pervious concrete
}

\section{Estudo da condutividade hidráulica com carga constante e variável em concretos permeáveis}
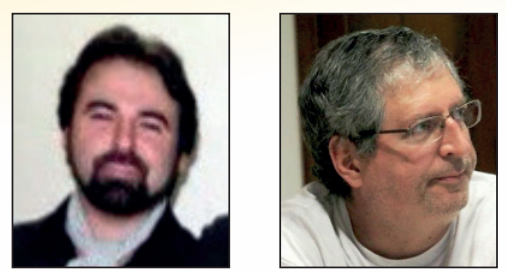

R. BATEZINI a rafaelbatezini@usp.br

J. T. BALBO a jotbalbo@usp.br

\section{Abstract}

The main goal of this paper is to show the analysis of the permeability characteristics of three different mixes of pervious concrete produced with the variation of the coarse aggregate size. Two different test methods were used to achieve the hydraulic conductivity of the samples: falling head and constant head permeability tests. Based on test results it is concluded that the pervious concrete mixes have shown to be good drainable materials. Besides, it was found that the permeability of the mixtures does not seem to depend on the size and gradation of the coarse aggregate.

Keywords: pervious concrete, permeameter, hydraulic conductivity, concrete pavements.

\section{Resumo}

Este trabalho tem por objetivo apresentar os resultados de ensaios de permeabilidade realizados para três misturas de concretos permeáveis produzidos com diferentes granulometrias, a fim de determinar a variação do potencial permeável destas misturas considerando as diferentes porcentagens de agregados graúdos na sua composição. Para determinação do coeficiente de permeabilidade foram empregados dois métodos: ensaio de permeabilidade com carga variável e com carga constante. A partir da análise dos resultados obtidos, pôde-se observar que os materiais estudados apresentam muito boas características de drenabilidade e que a variação da granulometria em termos de agregados graúdos não é fator preponderante para a variação deste parâmetro.

Palavras-chave: concreto permeável, permeâmetro, condutividade hidráulica, pavimentos de concreto. 


\section{Introduction}

The increasing of impermeable surface areas due to the accelerated and unplanned urban development has significant impacts on the hydrologic cycle, rising the peak runoff rate, which increase the probability of downstream flooding and inundation on the cities. Those events are commonly associated to demographic explosion and the lack of urban planning by government institutions.

In recent years, an alternative hydrological control concept has gained place in the Brazilian urban drainage scenario. The Best Management Practices (BMP) are techniques that aims to guarantee the storm water control to be absorbed into the ground, as near as possible from its source, avoiding runoff and consequently downstream flooding. The Environmental Protection Agency (EPA) has developed this concept in the 80s. It is based on storm water control planning in a basin scale by using civil structures in order to temporarily store surface runoff before infiltrating it into the subsoil (reservoirs, infiltration trenches, permeable pavements), in an attempt to compensate the effects of urbanization.

In addition, projects involving roads, highway, bus corridors, parking lots and other infrastructures in large urban centers, need to consider several technical and environmental requirements recommended by governmental transport agencies as well as by environmental agencies. Concerning environmental criteria, new regulations have been created in Brazil in order to restrict the percentage of impermeable surface areas in urban projects. Usually, at least $30 \%$ of the total project area is requested to be permeable. In this context, permeable pavements systems can be considered as a simple solution, which must have mechanical and hydraulic characteristics sufficient to withstand both the traffic loads and allow water infiltration from the storm water into its structure, reducing the runoff by almost $100 \%$.

Permeable pavement is a structure that allows air and water to drain through its layers. This infiltration device absorbs most part of the surface runoff into an open-graded stone reservoir placed over the subgrade. Once the water is absorbed and temporarily stored into the open-graded base, it can infiltrates into the subsoil depending on soil drainage characteristics, or a drainage system can conduct it to a different reservoir. The permeable pavement base and sub-base, which stores the runoff, is characterized as an open-graded matrix with reduced amount of fine aggregates.

\subsection{Justification}

In the Brazilian context, there is still no much research on the use of pervious concretes and its long-term performance, and the num-

\begin{tabular}{|c|c|c|c|}
\hline \multicolumn{4}{|c|}{$\begin{array}{c}\text { Table } 1 \text { - Coarse aggregate proportions } \\
\text { used in mixes }\end{array}$} \\
\hline \multirow{2}{*}{ Mixtures } & \multicolumn{3}{|c|}{$\%$ of retained material on the sieve } \\
\hline & $9.5 \mathrm{~mm}$ & $6.3 \mathrm{~mm}$ & $4.75 \mathrm{~mm}$ \\
\hline M1 & 0 & 100 & 0 \\
\hline M2 & 0 & 50 & 50 \\
\hline M3 & 30 & 40 & 30 \\
\hline
\end{tabular}

ber of publications on this topic is scarce. Considering the potential environmental and economic advantages on using this kind of material as the surface layer of permeable pavements for light and heavy traffic compared to the other materials, it can be seen the importance of carrying out more detailed studies on the subject, including the assessment of hydraulic conductivity of pervious concrete. The main goal of this study is to show the results of a laboratorial study on the hydraulic conductivity of pervious concrete obtained by constant and falling head permeability tests. The tests was carried out on specimens produced by three different pervious concretes mixtures with the variation of the coarse aggregate gradation, focusing on determining the influence of the gradation on the material's permeability.

\section{Materials and experimental program}

\subsection{Materials, molding and curing}

Cylindrical specimens of the pervious concrete were prepared in order to perform the hydraulic characterization tests. The molding procedures were conducted at Holcim Brasil laboratory at São Paulo. The laboratorial tests were carried out at Pavement Mechanics Laboratory and Pavement Technology Laboratory, both in the Transportation Engineering Department of the Polytechnic Schol of the University of São Paulo.

The mixture design applied on this study had been pre-set from the literature review, since there was no specific mix design procedure for pervious concrete by the time of the study. Thus, previously studied mix proportions had been considered in order to verify how the gradation of the coarse aggregate influences on the hydraulic behavior of the mixtures. Three pervious concrete mixtures were produced using different coarse aggregate gradation, as shown in Table 1.

The cement content range to produce pervious concrete observed in literature review goes from 340 to $400 \mathrm{~kg} / \mathrm{m}^{3}$. On this study, it was used $374 \mathrm{~kg} / \mathrm{m}^{3}$ of cement content. The coarse aggregate content was $1.660 \mathrm{~kg} / \mathrm{m}^{3}$ which represent 1:4,4 cement/aggregate proportion; the water to cement ratio of 0,3 was fixed according to other studies. Table 2 summarizes the material proportions used in this study.

The compaction molding procedure for the cylindrical samples (20 $\mathrm{cm}$ high and $10 \mathrm{~cm}$ diameter) consisted on rodding 15 times in three layers (Figure 1), followed by vibration for 10 seconds on a vibration table (Figure 2). The specimens were placed in a moist chamber at $98 \%$ relative humidity, and cured according to NBR 5738 [2]. All samples were demolded after 7 days, unlike conventional concrete, since pervious concrete did not show enough

Table 2 - Pervious concrete mixing ratio

\begin{tabular}{|cc|}
\hline Materials & Proportion \\
\hline Cement $\left(\mathrm{kg} / \mathrm{m}^{3}\right)$ & 374 \\
\hline Coarse aggregate $\left(\mathrm{kg} / \mathrm{m}^{3}\right)$ & 1,660 \\
\hline $\mathrm{w} / \mathrm{C}$ ratio (mass) & 0.3 \\
\hline Cement/aggregate ratio (mass) & $1: 4.4$ \\
\hline
\end{tabular}


Figure 1 - Sample compaction

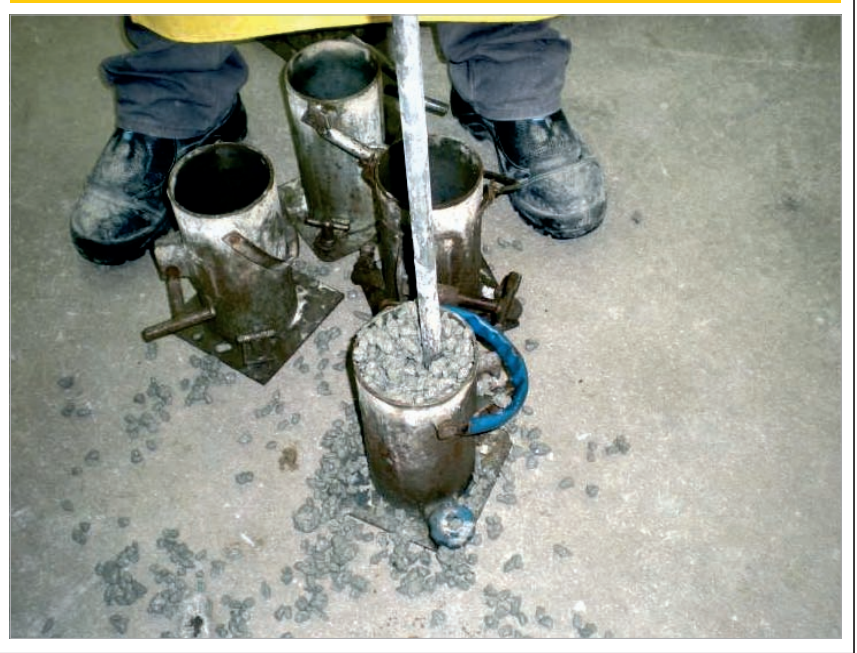

stable structure to be demolded after 24 hours, as recommended by the Brazilian standard.

\subsection{Permeability tests}

\subsubsection{Falling head permeameter test}

A falling head permeameter was constructed in the laboratory in order to carry out the permeability tests. The apparatus is equipped with a valve and an external level to check the water column height (Figure 3). Twelve samples were tested for each pervious concrete mixture in order to obtain a sufficient number of samples for statistical analysis of the results.

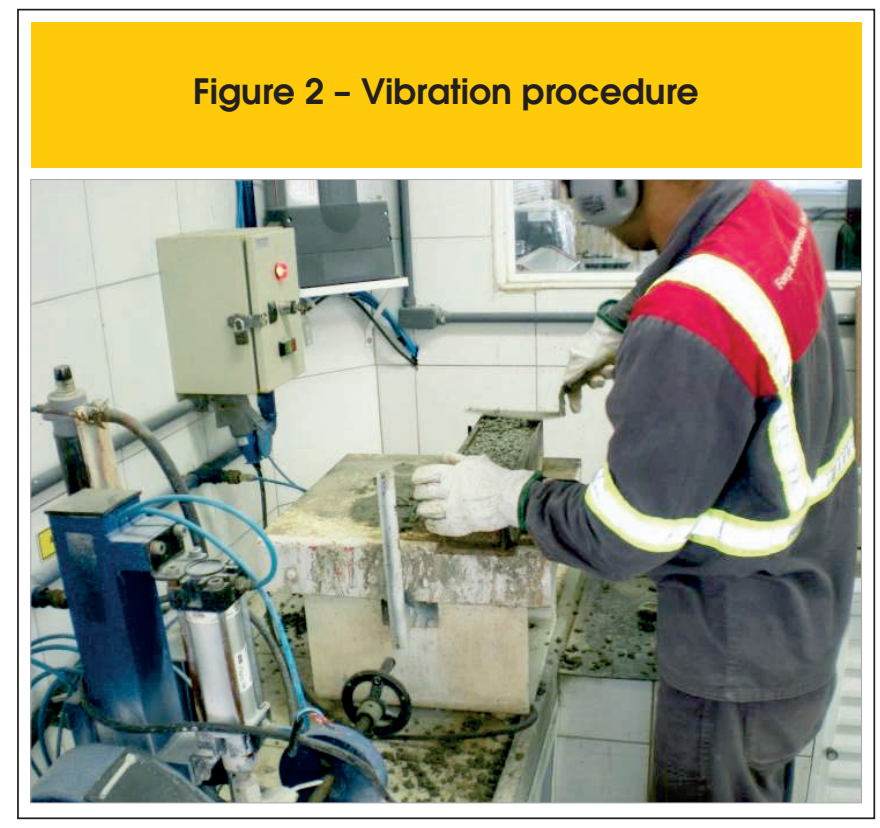

During the test the samples were wrapped in plastic film in order to avoid loss of water through its lateral surface. Furthermore, two silicone rings were used for sealing the bottom and the top of the samples were produced, avoiding water leaks during the tests. The tests were carried out 25 days after molding.

The test procedure consisted in adding water to the downstream end of the device to expel any air voids that may have been present in the sample. After complete sample immersion on water, the valve on the center of the permeameter was closed and the water column height was increased until $25 \mathrm{~cm}$ by the upstream. After opening the valve, the time to the water column height decrease from $25 \mathrm{~cm}$ to $5 \mathrm{~cm}$ was recorded. Equation (1) was used in order to determine the hydraulic conductivity of the samples.

$$
k=\frac{a L}{A t} x \ln \frac{h_{1}}{h_{2}}
$$

In Equation (1) k is the hydraulic conductivity ( $\mathrm{cm} / \mathrm{s})$, a is the cross-sectional area of the standpipe $\left(\mathrm{cm}^{2}\right), L$ is the length of specimen $(\mathrm{cm}), A$ is the cross-sectional area of specimen $\left(\mathrm{cm}^{2}\right)$, $\mathrm{t}$ is the time for water to drop from $h_{1}$ to $h_{2}(s)$, and $h_{1}$ and $h_{2}$ are the initial and final water level $(\mathrm{cm})$.

\subsubsection{Constant head permeameter test}

The constant head test is characterized by a constant water column height during the test. In Soil Mechanics, it is usually recommended to use the constant head test in order to determine its hydraulic conductivity of high permeability materials $\left(k>10^{-3} \mathrm{~cm} / \mathrm{s}\right)$, which is the case of the pervious concrete. However, all authors have published results of the falling head permeability tests in pervious concrete, since for practical purposes such as the material quality control in field, the use of falling head test seems to be simpler then the constant head, what makes it easier to compare the results in field with those obtained in laboratory.

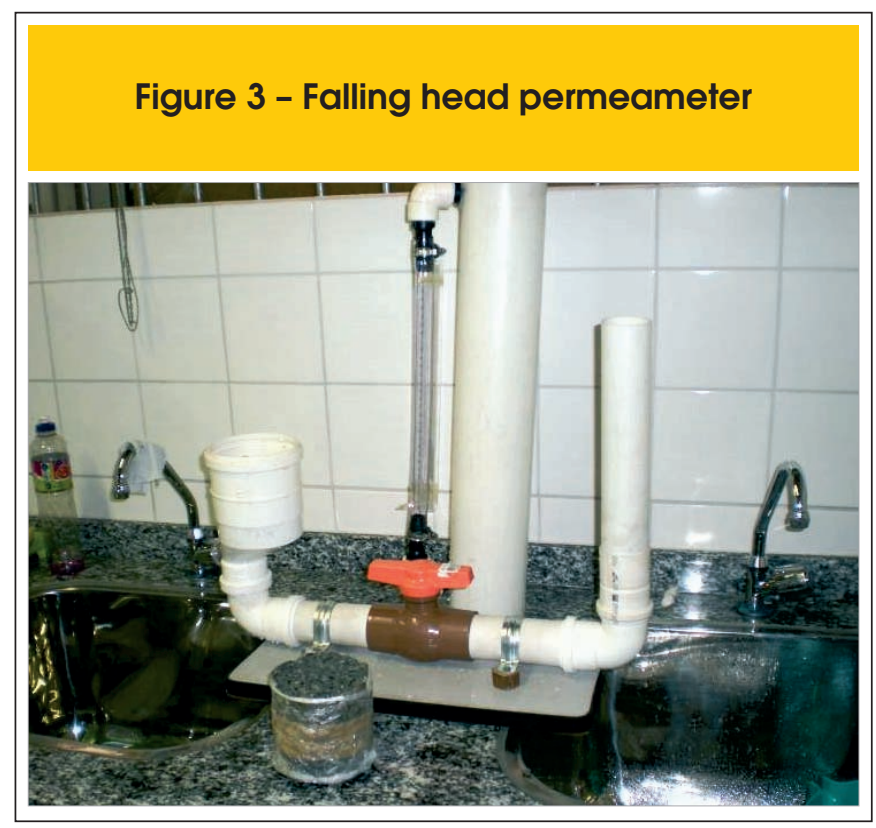




\section{Figure 4 - Constant head permeameter}

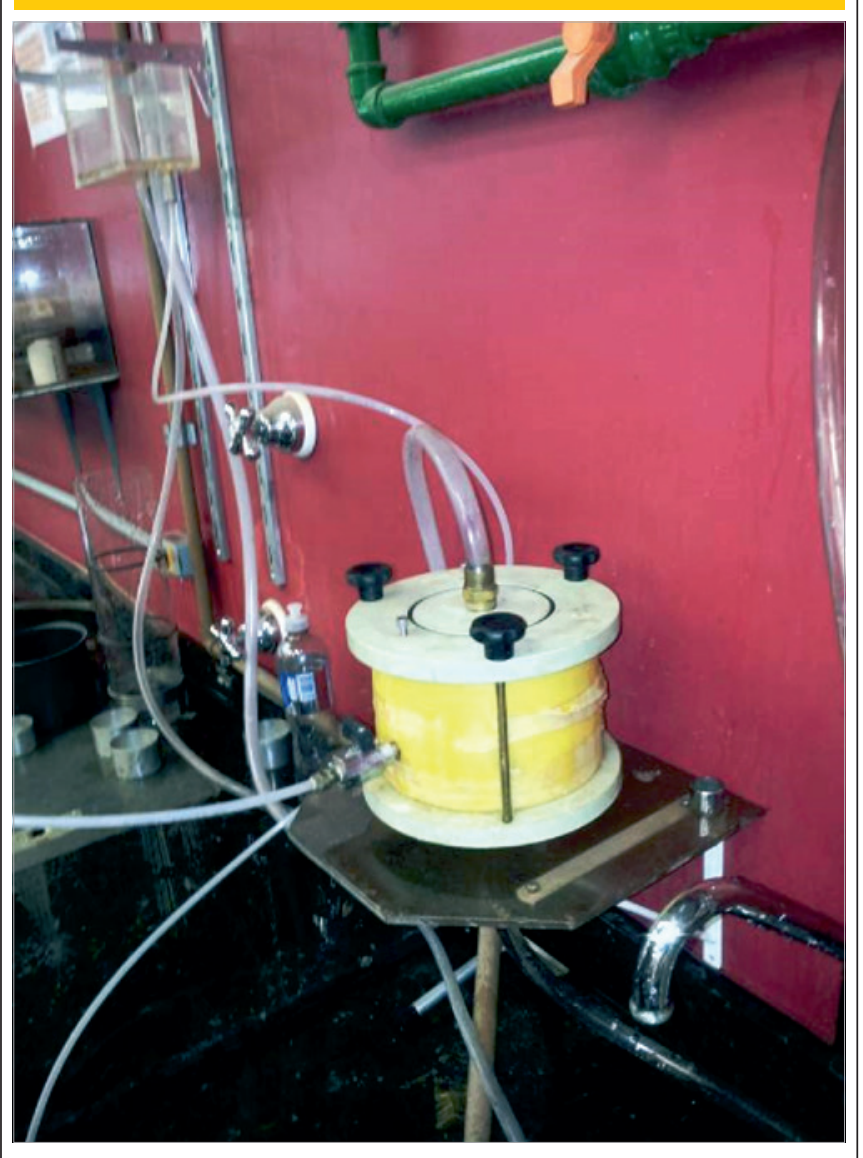

The apparatus is equipped in the bottom with a plastic ring where de specimen is placed (Figure 4). A flexible membrane positioned internally on the plastic ring is pressurized on the side of the samples in order to avoid water leaks by its lateral during the test. The container used to produce the water pressure is provided with an inlet and an outlet of water as well as by a lower safety outlet to prevent overflow.

The cylindrical cores were cut into four pieces in order to carry out the permeability tests, since de equipment has a $5.5 \mathrm{~cm}$ sample height limitation. The surface and the bottom parts of the specimen were discarded and just the remaining top and bottom central pieces were tested.

The control of the water column height was carried out by leveling the column height up in the container, which was calibrated by the incoming water flow. It was carried out several attempts to find the optimal column height for the testing material in order to maintain a laminar water flow, which tends to vary with the fluid velocity in the conduit.

The test was started by placing the sample on the plastic ring and pressuring the flexible membrane, sealing the core laterals. Then, water flow was released in order to fill up the entire system with water. The flow rate was increased until column height constancy. The water discharged was collected in a known-weight-recipient and the time for collect 750 to $1,000 \mathrm{~mL}$ of water was measured. Four trials were carried out for each sample and the hydraulic conductivity was calculated by the average of the obtained values. Once obtained the volume of discharge and the elapsed time for its collection, the hydraulic conductivity was determined by Equation 2:

$k=\frac{V . L}{h . A . t}$

In Equation (2) $k$ is the hydraulic conductivity $(\mathrm{cm} / \mathrm{s}), V$ is the volume of discharge $\left(\mathrm{cm}^{3}\right), L$ is the length of specimen $(\mathrm{cm}), h$ is the column height $(\mathrm{cm}), A$ is the cross-sectional area of specimen $\left(\mathrm{cm}^{2}\right)$ and $t$ is the time for discharge (s).

\section{Results and discussion}

Tables 3 to 6 show the test results for hydraulic conductivity and statistic data analysis. It can be observed that the average of

\begin{tabular}{|cc|}
\hline $\begin{array}{c}\text { Table } 3 \text { - Hydraulic conductivity results } \\
\text { in the falling head test }(\mathbf{c m} / \mathbf{s})\end{array}$ \\
\hline M1
\end{tabular}

Table 4 - Basic statistical analysis of hydraulic conductivity results obtained from falling head test

\begin{tabular}{|cccc|}
\hline \multirow{2}{*}{ Parameter } & \multicolumn{4}{c|}{ Hydraulic conductivity $(\mathrm{cm} / \mathrm{s})$} \\
& $\mathrm{M} 1$ & $\mathrm{M} 2$ & $\mathrm{M} 3$ \\
\hline$\mu$ & 0.565 & 0.630 & 0.703 \\
$\sigma$ & 0.058 & 0.065 & 0.054 \\
$\mathrm{CV}(\%)$ & 10.21 & 10.32 & 7.68 \\
$\mu=$ average; $\sigma=$ standard deviation; $\mathrm{cv}=$ coefficient of variation \\
\hline
\end{tabular}




\section{Table 5 - Hydraulic conductivity results in the constant head test $(\mathrm{cm} / \mathrm{s})$}

\begin{tabular}{|c|ccc|}
\hline \multirow{3}{*}{ Position } & \multicolumn{3}{c|}{ Mixtures } \\
\hline \multirow{3}{*}{ Top } & 0.13 & 0.13 & 0.14 \\
& 0.14 & 0.13 & 0.14 \\
\hline \multirow{3}{*}{ Bottom } & 0.13 & 0.13 & 0.14 \\
& 0.14 & 0.11 & 0.14 \\
& 0.14 & 0.13 & 0.14 \\
\hline
\end{tabular}

hydraulic conductivity values were similar for all the three mixes in both falling and constant head tests, indicating that the variation of the coarse aggregate gradation used in this study does not seem to affect the drainability characteristics of the pervious concrete. This condition is explained by the void ratio resultant for the mixtures, which also showed little variation [3], since void ratio seems to be directly associated to the drainability characteristics of pervious concrete produced without fines.

It had been observed generally low coefficient of variation for the results (below 11\%) in statistical analysis. Besides that, the results obtained by the constant head test were more homogenous, since the coefficient of variation is lower than that obtained in the falling head test.

It had been observed that the hydraulic conductivity obtained by the constant head test vary from $0.13 \mathrm{a} 0.14 \mathrm{~cm} / \mathrm{s}$. These results are within the range of results obtained by most authors that

\begin{tabular}{|cccc|}
\hline \multicolumn{3}{|c|}{$\begin{array}{c}\text { Table 6 - Basic statistical analysis of hydraulic } \\
\text { conductivity results obtained from constant } \\
\text { head test }\end{array}$} \\
\hline \multicolumn{4}{|c}{ Hydraulic conductivity (cm/s) } \\
Parameter & M1 & M2 & M3 \\
\hline$\mu$ & 0.14 & 0.13 & 0.14 \\
$\sigma$ & 0.008 & 0.009 & 0.002 \\
Cv (\%) & 5.66 & 6.80 & 1.50 \\
$\mu=$ average; $\sigma=$ standard deviation; $c v=$ coefficient of variation \\
\hline
\end{tabular}

studied these parameter in pervious concrete mixes, which published values ranging between 0.01 e $1.5 \mathrm{~cm} / \mathrm{s}[4 ; 5]$.

It was also noticed that the average of the results obtained by the two tests are considerable different since the values from the falling head test were higher. This may be attributed to the difference in equipment technology. In the falling head test, the sample was wrapped in plastic film intending to reduce or limit the water flow by its laterals. However, unlike the equipment used in the constant head permeameter, there was no external pressure applied to the cores, which may have caused a considerable loss of water by the specimen laterals, resulting in higher hydraulic conductivity values.

Figure 5 shows the variation of the hydraulic conductivity versus de void ratio variation of the two tests assessed in this study compared to the results published by other authors. It can be observed that the hydraulic conductivity values obtained in this study are very similar to those obtained by [6] in the case of the constant

\section{Figure 5 - Hydraulic conductivity variation obtained by the two methods versus void ratio variation}

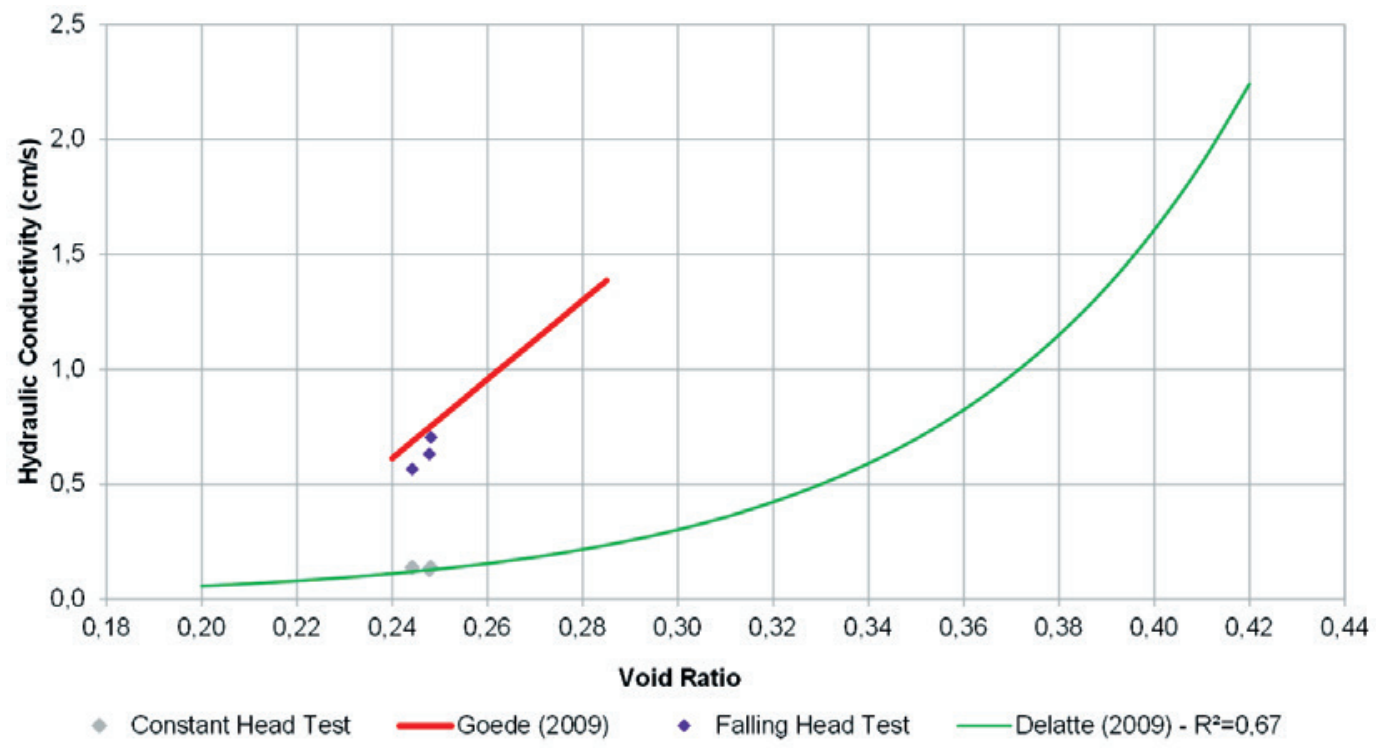


head test and void ratio around 0.25, approximately. However, [7] obtained values five times higher, which are equivalent to the results found out by the falling head test in this research, considering a void ratio of 0.25 , approximately. It must be pointed out that both former studies [6;7] used the falling head test.

\section{Conclusions}

This paper relates results of investigation on the hydraulic conductivity of three different mixes of pervious concrete without fines using constant and falling head permeameters. The main conclusions are summarized below:

- The coarse aggregate gradations does not appear to have significant effect on the results of hydraulic conductivity of the pervious concrete, since the values were very similar for all three mixtures;

- It was found that the coefficient of variation of the results were small (less than 11\%). Besides that, the result from the constant head test were less dispersed than those obtained in the falling head test;

- The differences between the dispersions in hydraulic conductivity results may be associated with the lateral confinement of the samples. The lateral sample confinement may not have been guaranteed in the falling head test due the limitations of the permeameter.

- The hydraulic conductivity coefficients obtained in this study are similar to those reported by other authors, and this parameter seems to be strongly related to the void ratio of the mixture.

\section{Acknowledgements}

The authors gratefully acknowledge support received by the Conselho Nacional de Desenvolvimento Científico e Tecnológico $(\mathrm{CNPq})$ - master's scholarship of the main author, and the Holcim Brasil by the support on molding the samples as well as to the Pavement Machanics Laboratory and Pavement Technology Laboratory of EPUSP.

\section{References}

[1] McCUEN, R. H. Hydrologic Analysis and Design. Englewood Cliffs: Prentice-Hall. 1989.

[2] ASSOCIAÇÃO BRASILEIRA DE NORMAS TÉCNICAS. NBR 5738: Molding and cure of cylindrical and prismatic concrete samples. (In Portuguese) Rio de Janeiro, 1994.

[3] BATEZINI, R. Preliminar study of pervious concrete as pavement surface layer for light vehicles parking areas. (In Portuguese) Master thesis, Department of Transportation Engineering, University of São Paulo, 2013.

[4] SCHAEFER, V.; WANG, K.; SULEIMAN, M.; KEVERN, J. Mix Design Development for Pervious Concrete in Cold Weather Climates. Final Report, lowa State University, 2006.

[5] MONTES, F.; HASELBACH, L. Measuring Hydraulic Conductivity in Pervious Concrete. Environmental Engineering Science V. 23, p. 960-969, 2006.

[6] DELLATE, N.; MRKAJIC, A.; MILLER, D. I. Field and Laboratory Evaluation of Pervious Concrete Pavements. Transportation Research Record: Journal of the Transportation Research Board. v. 2113, p. 132 - 139, 2009.
[7] GOEDE, W. G. Pervious Concrete: Investigation into Structural Performance and Evaluation of the Applicability of Existing Thickness Design Methods. Master thesis, Department of Civil and Environmental Engineering, Washington State University, 2009. 